\title{
DOSSIÊS
}

\section{PARLIAMENTARY FUNCTIONS PORTRAYED ON EUROPEAN PARLIAMENTS' WEBSITES}

\author{
Cristina Leston-Bandeira
}

\begin{abstract}
This article uses data from a pilot study on the websites of 15 parliaments in Europe to identify which parliamentary functions are portrayed on these websites. The pilot study undertook a contents analysis focused on four parliamentary functions: legislation, legitimation, representation and scrutiny, to ascertain the extent to which each of these functions is present on the websites analysed. As parliaments face difficulties of public perception, their websites become an important tool for dissemination of parliamentary work. And yet we know little about what these websites portray, when it comes to parliamentary activity. Are these websites a reflection of parliamentary work? To what extent do these websites express political debate? To what extent are these websites comprehensive to all of the roles performed by parliaments? This article shows that legislation is the main focus of parliamentary websites in Europe and representation the one that has less devoted space. This may go some way to explain why some parliamentary websites are considered as too dense and not user friendly. We also show that parliamentary websites tend to focus on parliamentary outputs to the detriment of parliamentary actors. Because of their institutional collective representation, parliaments are cautious in focusing on politicians or parties; instead they focus on what parliaments produce (laws, questions, debates, etc.). Again, this goes some way to explain why parliaments' websites may not be as engaging as one may expect, simply because they are not meant to reflect political debate, but simply to facilitate it.
\end{abstract}

KEYWORDS: Internet; European parliaments; parliaments'websites.

\section{INTRODUCTION}

This article uses data from a pilot study on the websites of 15 parliaments in Europe to identify which parliamentary functions are portrayed on these websites. The pilot study undertook a contents analysis focused on four parliamentary functions: legislation, legitimation, representation and scrutiny, to ascertain the extent to which each of these functions is present on the websites analysed. This study is part of ongoing research and focuses here only on the contents of the

\footnotetext{
${ }^{1}$ Earlier drafts of this article were presented at the Eighth Workshop for Parliamentary Scholars and Parliamentarians, Wroxton, United Kingdom, July 2008 and at the Centre for European Union Studies Seminar Series, University of Hull, November 2008. The author is grateful to the participants of both of these events who gave feedback on the paper. The author is also grateful to Veronika Dlouha, Michal Opela and Rosa Vicente-Merino for their work in collating data for this study. This article is based on a pilot study which is part of ongoing research. The author would be very grateful for any feedback to be sent directly to her, in particular with regards to the conceptualisation of the function Indexes.
}

websites, without integrating structure or style. We recognise that these are crucial to understanding a website, but we aim in this article to merely focus on content for a preliminary discussion of how parliaments portray the four parliamentary functions identified. Further research will integrate structure and style into the analysis. This analysis shows that legislation is the main focus of parliamentary websites in Europe and representation the one that has less devoted space. We also show that parliamentary websites tend to focus on parliamentary outputs to the detriment of parliamentary actors.

\section{ASSESSING PARLIAMENTS' WEBSITES THROUGH PARLIAMENTARY FUNCTIONS}

The internet plays an increasingly important role in communicating and forming public opinion, being a key tool in the relationship between political institutions and the public. Understanding how a central political institution such as parliament uses the internet is therefore crucial to address some of the challenges faced by today's democracies such as political apathy and distance between citizens and politicians. The potential importance

Rev. Sociol. Polít, Curitiba, v. 17, n. 34, p. 13-27, out. 2009 
played by information and communication technologies (ICT) for parliaments is shown by developments such as the Global Centre for ICT in Parliament, a joint venture between the United Nations Department of Economic and Social Affairs (UNDESA) and the Inter-parliamentary Union (IPU) together with a group of parliaments, which aims to promote and strengthen the development of ICT in parliaments across the world (GLOBAL CENTRE FOR ICT IN PARLIAMENT, 2009). This initiative actively promotes and supports events, conferences, networks and studies in this area. ICT can potentially enhance parliament's work considerably by helping towards more transparent and accessible institutions, as well as promoting an active engagement of citizens in the political process.

And yet the implementation of ICT by parliaments is not always a straight forward process. By their very nature, parliaments are institutions where the implementation of rapid processes (such as the ones that characterise ICT) presents difficulties. Parliaments are collective and large institutions, which means that it may take longer to reach decisions; they are also public institutions and need to show transparency in decision-making. Again, this leads to long decisionmaking processes, often not very flexible and often far too broad to encompass agreement between different political views. In comparison to parties, for instance, the parliamentary institution brings a higher level of complexity in the application of ICT as it needs to obey to a much larger - but also more difficult to account for - drive. ICT brings therefore huge potential for parliaments, but also significant challenges. One of its biggest challenges is to conciliate what ICT can provide for in terms of enhanced democracy (with the expectations that derive from the rapid technological development) and the actual parliamentary decision-making process that underlie the way parliament adopt ICT. This is particularly clear when it comes to the parliaments' websites, raising a number of questions: to what extent, for instance, does a parliament's website correspond to what parliaments do and what citizens expect? Who decides what to include on a parliament's website and what its focus should be? Or, simply, what is the focus of parliamentary websites?
Throughout the 1990s European parliaments introduced and developed their own websites and, according to the Inter-Parliamentary Union, $87 \%$ of these parliaments were online by 1998 (INTERPARLIAMENTARY UNION, 2000, p. 3). The question today is not whether they are online, but how they are online; that is, what is their focus. The basic features included in these websites have been identified in surveys ${ }^{2}$. What remains unknown, however, is whether this expansion has brought an enhancement of parliamentary activity; that is, the extent to which 1) the websites reflect the work being developed in parliament and 2) the extent to which the online presence can actually enhance parliamentary activity. We propose to address these questions by focusing on key four functions played by parliaments in Europe and the extent to which their websites reflect these functions.

Parliaments in Europe play four key functions (in alphabetical order): legitimation, legislation, representation and scrutiny (NORTON, 1998). If the internet is to enhance parliamentary activity, then it should enhance these four functions. Furthermore, the use of the internet should provide parliaments with a unique opportunity to overcome constraints resulting from institutional factors. The internet provides a cost effective and efficient means through which politicians can reach out to a very wide range of publics. It could therefore be a powerful tool to enhance parliaments' functions of legitimation, legislation, representation and scrutiny. In a world where the internet has become an integral part of peoples' routines, parliaments' websites can be much more than a mere information repository; they can be a key mechanism promoting active citizenship, as well as a more dynamic relationship with other stakeholders such as pressure groups.

However, we still know little about the detail of what these websites include and what they add to the institution itself. To what extent are the websites of parliaments in Europe adding value to these institutions? And what do the different experiences in Europe show us about how the internet has been used by parliaments? One key challenge arising from these questions is to

2 See the most recent and comprehensive in Global Centre for ICT in Parliament (2008a). 
ascertain whether parliaments' institutional factors have an impact on the way their websites are being designed and used. Parliaments in Europe are organised very differently according to institutional factors such as their method of election or their structure. Likewise, parliaments play different functions according to their institutional characteristics; some lead naturally to a more representative role (such as the single-member constituency based British House of Commons) other to a more legislative based role (such as the German Bundestag). In order to fully evaluate parliaments' websites, and the role they play, one needs to take into account their wider off-line context (LESTON-BANDEIRA, 2007). The very few studies on this so far have not examined the institutional context in which parliaments function (NORRIS, 2001; TRECHSEL et alii, 2003; COLEMAN 2006; SETÄLÄ \& GRÖNLUND, 2006; GLOBAL CENTRE FOR ICT IN
PARLIAMENT, 2008a). Focusing on parliamentary functions and the way these are portrayed on their websites is a first step towards providing a more integrated understanding of parliaments' websites and the extent to which these enhance, hinder or simply reproduce what parliaments do off-line.

\section{THE STUDY}

To determine which parliamentary functions are portrayed on parliaments' websites, we undertook a pilot study which consisted of a contents analysis of the websites of 15 parliaments in Europe (11 national, three sub-national and one supra-national) ${ }^{3}$. This pilot study is part of ongoing research looking at the extent to which parliaments' websites have brought effective changes to parliamentary activity in Europe. This contents analysis was carried out in June 2008 and so it should reflect the websites at that moment in time. The pilot includes the following parliaments:

TABLE 1 - PARLIAMENTS FOR THE PILOT STUDY

\begin{tabular}{|l|c|c|c|}
\hline COUNTRYiREGION & $\begin{array}{c}\text { ELECTORAL } \\
\text { SYSTEM }\end{array}$ & POLITICAL SYSTEM & TYPE OF DEMOCRACY \\
\hline Austria & PR list & Semi-presidential & Established democracy \\
Belgium & PRlist & Parliamentary & Established democracy \\
Czech Republic & PRlist & Parliamentary & New democracy \\
European Union & n.a. & n. a. & n.a. \\
France & Majority & Semi-presidential & Established democracy \\
Germany & Mixed & Parliamentary & Established democracy \\
Ireland & PR sTV & Semi-presidential & Established democracy \\
Northern Ireland & Mixed & n. a. & Established democracy \\
Poland & PRlist & Semi-presidential & New democracy \\
Scotland & Mixed & n. a. & Established democracy \\
Slovakia & PR list & Semi-presidential & environment \\
Spain & PR list & Parliamentary & New democracy \\
Switzerland & PR list & Parliamentary & Established democracy \\
United Kingdom & Majority & Parliamentary & Established democracy \\
Wales & Mixed & n. a. & Established democracy \\
& environment \\
\hline
\end{tabular}

SOURCE: The electoral systems classification follows International Institute for Democracy and Electoral Assistance (2009); the political systems classification is according to LeDuc et alii (2002) and White et alii (2007); and the type of democracy is determined according to whether democracy has been in place for 50 or more years (Established democracy) or less than 50 years (New democracy).

NOTE: n. a.: not applicable.

\footnotetext{
${ }^{3}$ When bicameral, we have focused on the lower chamber.
} 
The contents analysis sought to map the websites according to the four parliamentary functions identified above: legislation, legitimation, representation and scrutiny. More specifically we aimed to identify how each site addresses these functions, in terms not only of the type of information included for each function, but also the level of detail and emphasis given to each. The results analysed in this article refer in particular to a number of variables that have been dichotomised. These variables are all coded in the same way and aim to check whether a particular feature exists or not; if the feature exists it is coded as 1 (one), if it doesn't, then it is coded 0 (zero). This allows the creation of an index for each parliamentary function which eases comparisons across variables and case studies. Each index is an average of the relevant dichotomised variables; the closer to 0 (zero) the weaker the index, the closer to 1 , the stronger.

The Legislation index assesses the amount of information given on bills and amendments, as well as the process associated to the consideration of each bill. It encompasses therefore variables such as whether information is given on the bill's author, for example, or whether links are given to its debate (for list of variables see "Appendix - Coding Frame for Contents Analysis of Websites"). All information available on the website which is specific to legislation should come under this index. The legislation function is the clearest one in terms of what parliaments are expected to do and also the most focused one. Its conceptualisation in terms of how this is portrayed on the site is therefore reasonably straightforward.

The Legitimation ${ }^{4}$ index assesses features which provide for overall knowledge and understanding of the parliamentary institution. The function of legitimation helps to maintain political support for the political system and includes roles such as a general provision of information about the political system, but can also refer to processes of "safety-valve", 5 that is the release of tensions expressed in society. This is the function that

\footnotetext{
4 By "legitimation" we are following the concept as developed and employed by Robert Packenham (1970).

5 Again, the specific function of "safety-valve" follows the legitimation concept developed by Packenham (1970) and systematised by Norton (1990, p. 6).
}

raises the most difficulties in its conceptualisation. To a large extent the "safety-valve" function can only be portrayed with a synchronous analysis which looks at a period of time, rather than just a specific point in time; i. e. it would need to include a dynamic analysis, rather than just a static one. To assess the extent to which parliaments' website reflect their "safety-valve" function, one would need to analyse a period of time to account for features such as, for example, news releases on an important debate in parliament, or the hearing of a specific pressure group of strategic importance at a particular moment in time, as another example. Our Legitimation index does not include those features as it is based on a static contents analysis of the websites - that is, all websites were analysed at one moment in time rather than over a period of time. Our Legitimation index includes therefore features such as the historical and contextual information about parliament, access to key regulatory documents, but also the existence, or not, of a separate section for a younger audience.

This function is differentiated from the one of representation which focuses solely on the availability of links and information about representatives, be it MPs, parties and/or parliamentary groups. The Representation index therefore measures the extent to which parliaments foresee specific sections of their websites to the contact with and the activity and views of the parliamentary representatives. This could be in the form of links to MPs or parties' websites, for example, but also in terms of information on parliamentary activity organised and displayed according to these representatives. It also looks at the provision, or not, of online debate spaces such as blogs managed by representatives.

The variables under Scrutiny look at the existence, or not, of information and access to scrutiny tools such as written questions to the government, committees of enquiry or interpellations. The type of scrutiny tools available differs considerably from parliament to parliament and the contents analysis took this into account. Where a scrutiny tool does not exist, this was not accounted for either way, being simply excluded from the index. This does not affect the value of the scrutiny index, as the average of the variables is calculated in terms of the number of variables input into the Index. The type of variables recorded 
for scrutiny are similar to the ones for legislation, such as the level of detail of information and access given to, for example, questions to the government; in terms of author of the question, availability of link to the actual question, link to the debate (or official parliamentary journal), and so on. Again, as for the other above functions, for more details see the Appendix, which includes the general Coding Frame used for this contents analysis.

The analysis below focuses on these four Indexes identifying the extent to which each function is portrayed on the websites of the 15 parliaments included in this study. The analysis below shows that, overall, legislation is the main function represented on parliaments' websites, and representation the least. We also try to ascertain the extent to which the focus of these websites in terms of parliamentary functions - differs from the role played by the actual parliaments.

IV. LEGISLATION, LEGITIMATION, REPRESENTATION AND SCRUTINY ON EUROPEAN PARLIAMENTS' WEBSITES

Figure 1 gives the values of the Legislation Index per country. The closer to 1 the stronger the index, that is the more that parliament's website dedicates space to the function of legislation.

FIGURE 1 - LEGISLATION INDEX

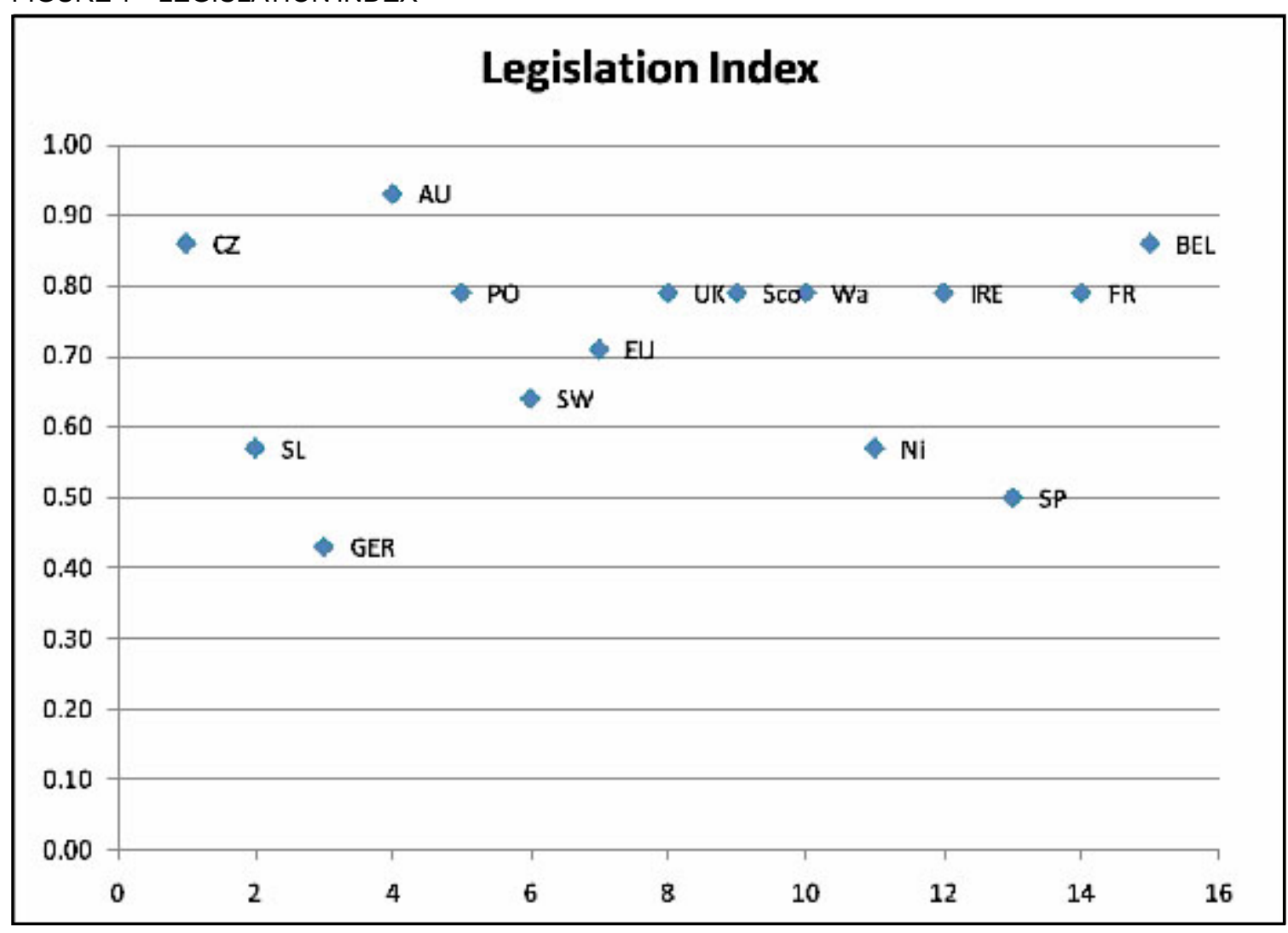

SOURCE: The Parliaments' Websites.

Figure 1 shows that Legislation has a strong presence on the websites of European parliaments. In many ways, this is not a surprising finding as one of the original functions for parliaments was the legislative role: to propose, amend and pass legislation. And even if a parliament does not have an effective role in passing legislation it does "giv[e] assent to binding measures of public policy" (NORTON, 1992, p. 1), by providing the constitutional framework through which (in most cases) legislation is produced. Still, in reality, parliaments today "only rarely actually draft legislation” (BERGMAN et alii, 2006, p. 117) and the other roles (such as scrutiny) actually take a much bigger part of daily parliamentary activity ${ }^{6}$.

6 See contributions to that effect in, for example, Wiberg (1994), Norton (1998) and Strøm et alii (2006). 
So, from that point of view, it is surprising that the Legislation Index is so high for the majority of our parliaments. Parliaments obviously perceive this as an important function that needs to be reflected on their websites.

Not only the average for the Legislation Index is by far the highest out of the four functions (see Table 2 at the end of this section), at 0.72, but also all except one (Germany, at 0.43 ) have a value of 0.50 or above. The low value for Germany is an interesting find that needs further investigation as this is a parliament generally considered as having an important role in legislation ${ }^{7}$, at least in comparison with its counterparts in Europe. This could be a case where the parliamentary website is not adding value to the parliamentary role, not giving a full picture of parliament's activity in this area. It could also reflect the fact that the German Bundestag is characterised as a "working parliament" (SAALFELD, 1998) - that is where parliamentary activity is focused on detailed amendment of legislation in committee based, a lot of which is not necessarily visible to the outsider. On the other hand Germany's Scrutiny
Index is the highest one (together with Austria). Figure 1 also shows that Austria is the parliamentary website with the highest value for its Legislation Index, at 0.93 - very close to 1.00 indicating that their website has a very comprehensive cover for legislative outputs and processes. The majority of the parliaments are clustered around 0.80 (Belgium, Czech Republic, France, Ireland, Poland, Scotland, UK and Wales) confirming again the importance given to legislation on these websites. To note in particular the French case (0.79), a parliament known for its weakness and where government can pass considerable legislation outside parliament (HAYWARD, 2004; THIÉBAULT, 2006); a parliament where the legislative role is therefore far from a strong one; and yet its website puts considerable focus on this role.

In terms of the institutional characteristics of these parliaments, there is no clear pattern in the way their websites score in the Legislation Index. Figure 2 gives the values for the Legitimation Index by country and here the distribution of the values is rather different from the one above.

\section{FIGURE 2 - LEGITIMATION INDEX}

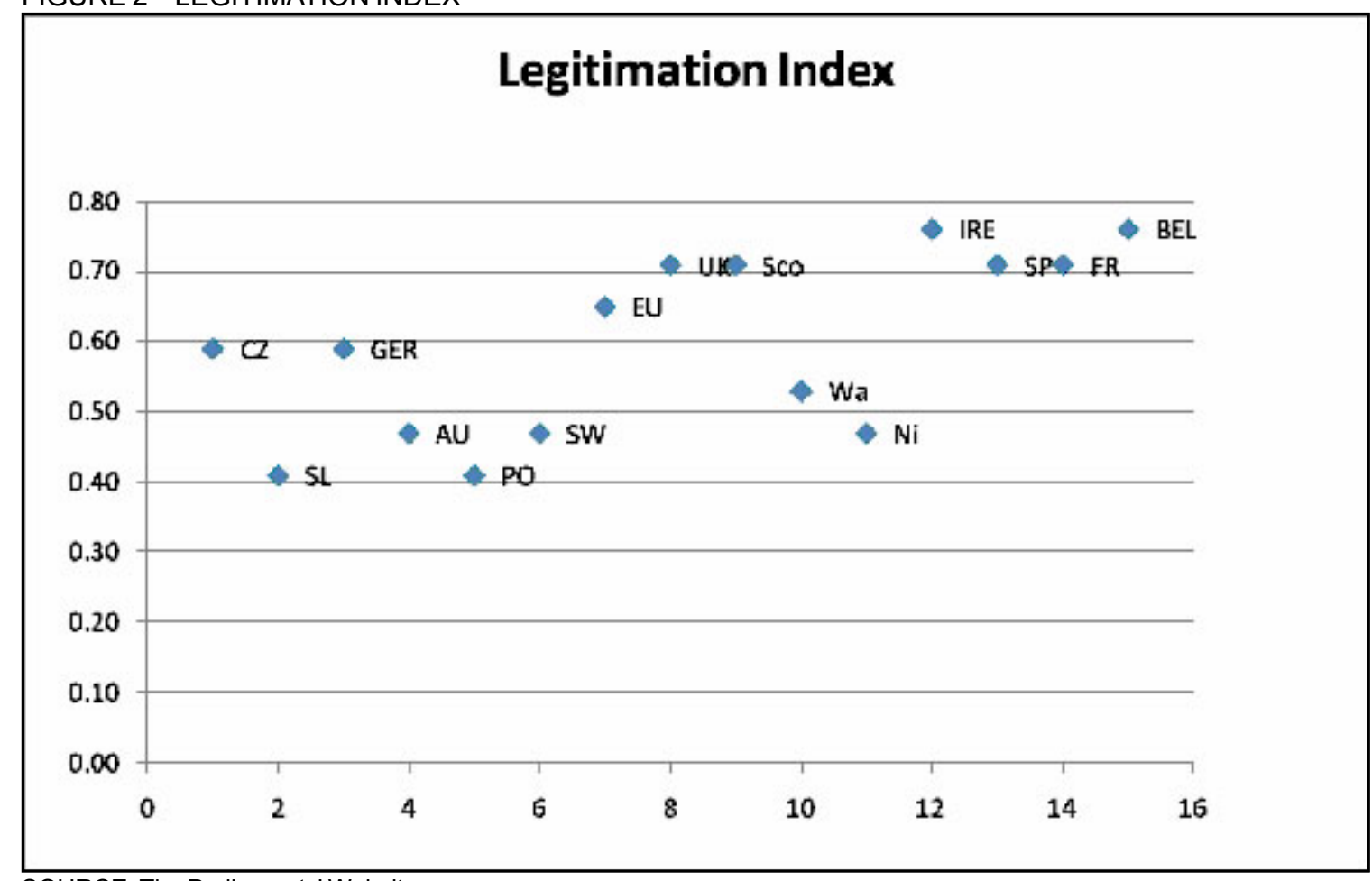

SOURCE: The Parliaments' Websites.

\footnotetext{
7 See, for example, Norton (1994) and Saalfeld (1998).
} 
Overall, the values are still quite high, though considerably lower than Legislation, with an average of 0.59 (see Table 2). Interestingly the lowest values for Legitimation are to be found in new democracies Poland and Slovakia ( 0.41 for both) - where one may find a more compelling argument for a strong focus on legitimation in order to support the development of the new democracy. Belgium and Ireland give considerable importance to the Legitimation function displaying the highest values both at 0.76 . To note the relatively high value again for France $(0.71)$ indicating again that its website is a valued means of communication and enhancement of this institution.

By reinforcing the Legitimation function on their websites these parliaments are giving particular importance to disseminating what these parliaments stand for and in educating citizens about the role played by parliament in their political systems and history. These may be seen as examples where the parliamentary websites are likely to be adding value to the parliaments' legitimation role. The internet presents excellent opportunities for this function, as it allows for a much more effective dissemination of what parliament is about then any other means of communication offer.

Figure 3 gives the values for the Representation Index by country and shows surprising results. Representation is the function with the lowest average out of all four functions, with a mean value of only 0.47 (see Table 2). This may be seen as counter-intuitive as one would imagine that the main aim of a parliamentary website would be to reinforce the role of representation. Partly, this may be due to the conceptualisation of this function. In many ways everything to do with parliamentary activity is about Representation and therefore it would be difficult to isolate variables that express this function. Still this Index reflects the level of detail given to access and information about MPs, parties and parliamentary groups. Even if this needs to be interpreted with care for each case study taking into account their method of election (which can lead to a higher focus on the MP individually considered or on the party), the Index does reflect what is visible on the websites: that access to parliamentary output is privileged in detriment to access to the parliamentary actors.

\section{FIGURE 3 - REPRESENTATION INDEX}

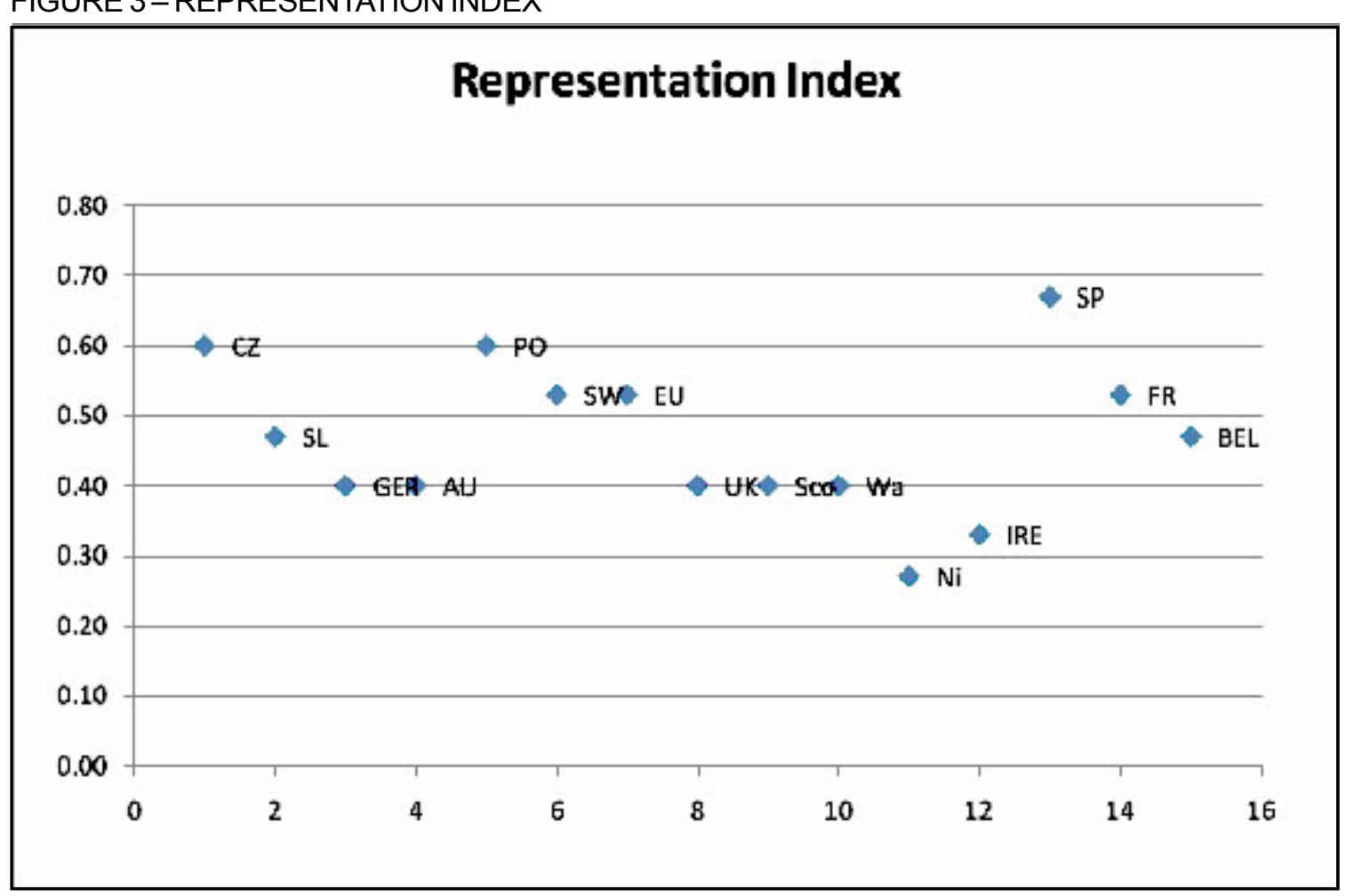


The parliaments with the lowest value for the Representation Index are Northern Ireland (at the very low value of 0.27 ) and Ireland (at $0.33-$ though here the Legitimation Index was very high). More surprising is the value for Spain which is the highest of Representation at 0.67 . This is surprising taking into account the proportional representation closed list d'Hondt system that elects Spanish MPs. This electoral system tends to lead to strongly centralised party systems, where the party channel of representation tends to dominate (rather than individualised by MP or even parliamentary group). This also tends to lead to a more distant relationship with citizens in terms of the representative mandate (NORTON \& LESTON-BANDEIRA, 2005; OÑATE, 2005). Could this be seen as a case where the parliamentary website adds value to the parliamentary role? Evidently considerable effort has been put into using the website to make the representative link more visible, through information and links relevant to both individual MPs and the parliamentary groups; to note, for example, the direct links to MPs' individual blogs and personal websites.
Figure 4 shows the Scrutiny Index by country. This is the Index with the fewest differences between case studies ${ }^{8}$. As Table 2 shows, the standard deviation for Scrutiny is the lowest one at 0.08 , which indicates very few differences in the level of attention given to scrutiny between the websites of our case studies. This is clear in Figure 4 which shows that the majority of the case studies congregate around the value of 0.50 . The two countries that stand out are Austria and Germany with the highest values for Scrutiny at 0.68 in both cases. The parliamentary website which seems to have the lowest focus on scrutiny is the British one, which may well correspond to its parliamentary role. Still, taking into account that the function of scrutiny seems to be the main priority in recent parliamentary developments in Europe (see WIBERG, 1994; NORTON, 1998; STRØM et alii, 2006), it is surprising to find such low values. The information about the activity of scrutiny is surely present on parliaments' websites, but it is the way this information is presented that is not very prominent, particularly when compared to legislation. The scrutiny function does not seem to receive as much attention as the legislative one in the way parliaments' websites are organised.

FIGURE 4-SCRUTINY INDEX

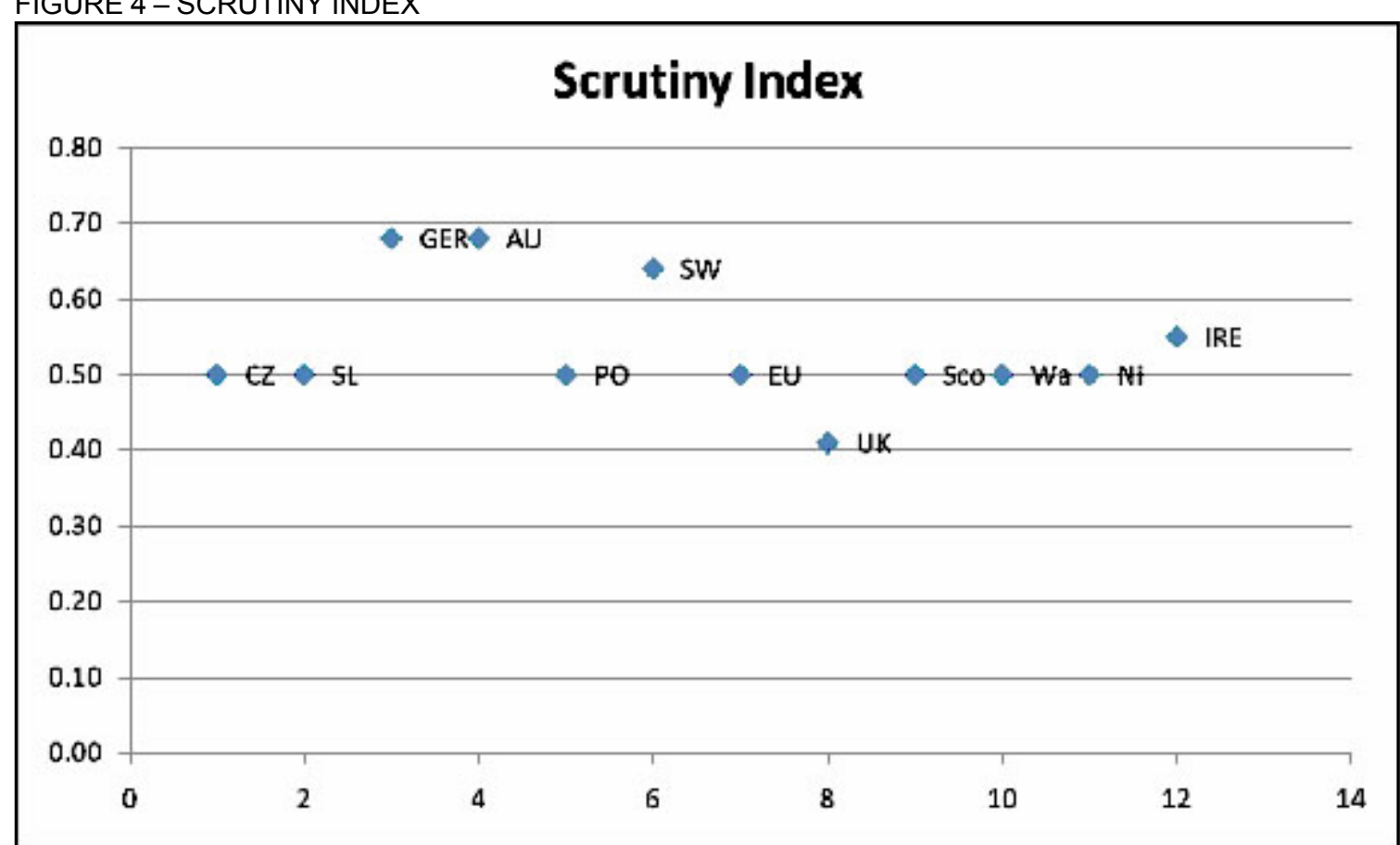

SOURCE: The Parliaments' Websites.

8 The Scrutiny Index does not include data yet for the following case studies: Belgium, France and Spain. 
Table 2 gives a summary of descriptive on above: statistics for the four Indexes as commented

TABLE 2 - MINIMUM, MAXIMUM, MEAN AND STANDART DEVIATION FOR THE FOUR INDEXES

\begin{tabular}{|l|c|c|c|c|c|}
\hline & N & MINIMUM & MAXIMUM & MEAN & $\begin{array}{c}\text { STD. } \\
\text { DEVION TION }\end{array}$ \\
\hline Legislation Index & 15 & .43 & .93 & .7190 & .14404 \\
Legitimation Index & 15 & .41 & .76 & .5961 & .12746 \\
Representation Index & 15 & .27 & .67 & .4667 & .10983 \\
Scrutiny Index & 12 & .41 & .68 & .5379 & .08411 \\
\hline
\end{tabular}

SOURCE: The Parliaments' Websites.

The analysis function by function shows that, overall, Legislation is the main function that parliaments choose to focus on in their websites and that Representation is the least important one. This is an important finding that needs further investigation, in particular taking into account the differences between institutional contexts of each parliament. But, in any case, this finding supports one of the conclusions reached at the workshop Parliaments in the Digital Age (LESTONBANDEIRA \& WARD, 2008, p. 49). Parliaments face an inherent paradox in establishing their websites: as an institution representative of all citizens, parliaments (and their non-party staff) are bound by a-partisan ethics. What the institution of parliament promotes needs to be fair to all political forces represented in parliament. The issue of neutrality is therefore very important and is reflected on parliaments' websites. This explains also that parliaments' websites tend to focus on parliamentary outputs rather than the parliamentary actors. However, parliamentary politics in Europe is about party politics. And by making their websites neutral, and not a vehicle for the political discussions, parliaments may not be reflecting the politics arena which is often what leads citizens to engage with politics. Figure 5 maps all four Indexes in one graph:

FIGURE 5 - INDEXES FOR THE FOUR PARLIAMENTARY FUNCTIONS

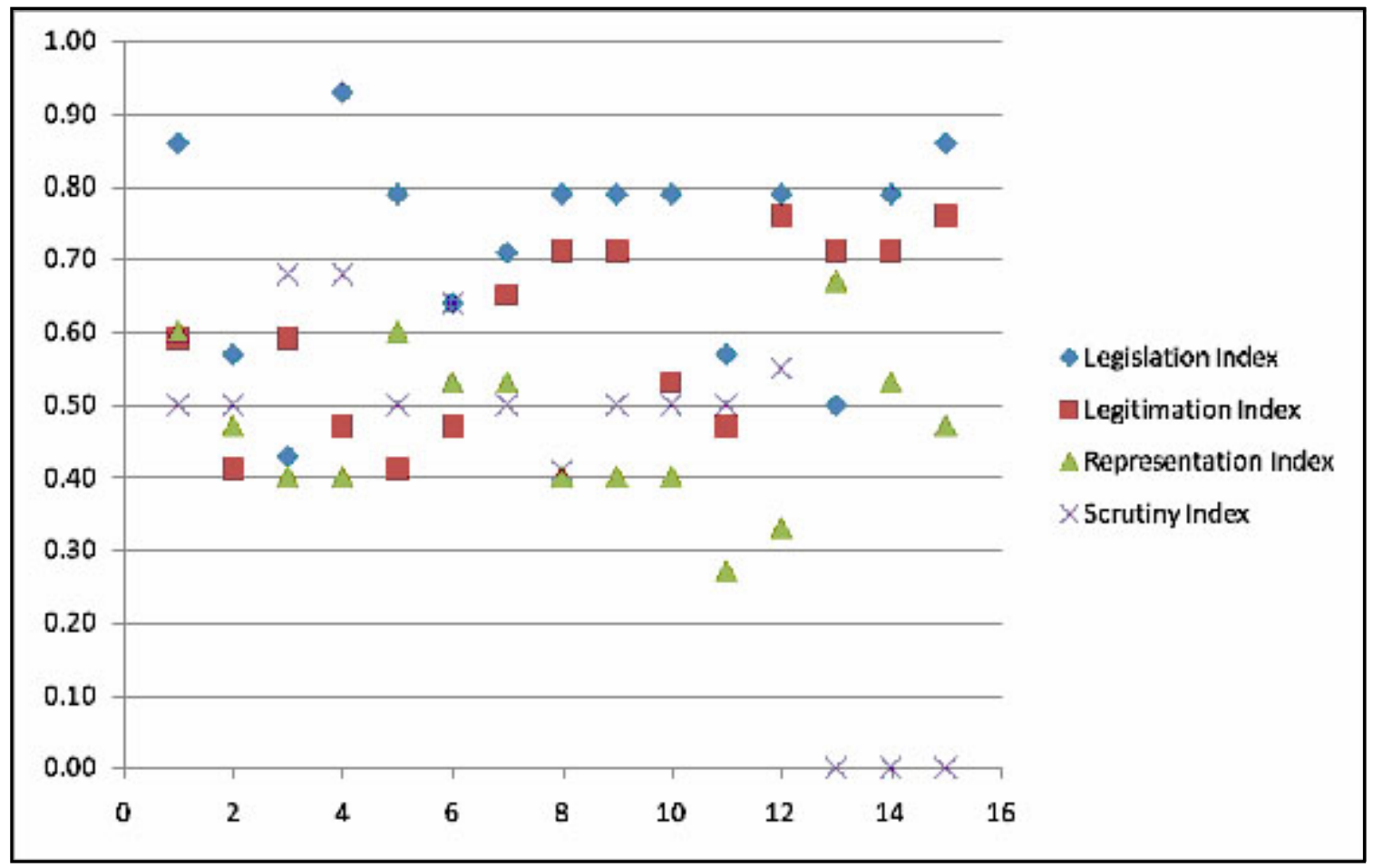

SOURCE: The Parliaments' Websites. 
This preliminary analysis also shows that in most of the case studies there are considerable differences between the several Indexes. No case study dedicates its website to all four functions at the same way, having usually one or two functions that dominate to the detriment of the other two. Likewise, there does not seem to be always a correspondence between what parliaments do and what is portrayed on their website. This raises a number of questions, namely about the process of deciding the contents (and how this is organised) of a parliamentary website. To what extent, for example, are parliaments' websites the result of evolving options and decisions, or to strategic plans? To what extent are the politicians themselves involved in these decisions, or parliamentary staff? To what extent is staff directly involved in parliamentary activity part of the decision-making process relating to the websites? These are questions that need to be addressed and which go beyond the contents of the websites analysed in this pilot study.

\section{CONCLUSIONS}

Based on a pilot study which undertook a contents analysis of the websites of 15 parliaments in Europe, this article set out to identify the parliamentary functions that are portrayed on these websites. This showed that Legislation is by far the main priority of parliamentary websites in Europe, despite the fact that there is considerable literature showing that parliaments' effective role in legislation is in fact very weak. This focus on legislation is visible on a number of documents and policies that advise on parliaments' websites, such as the draft new Guidelines for Parliamentary Websites issued in November 2008 for discussion (GLOBAL CENTRE FOR ICT IN PARLIAMENT, 2008b), as well parliamentary staff's discourse on their websites ${ }^{9}$. Part of this focus could arise from the complexity of legislation (though that would also apply to scrutiny), but there also seems to be a drive from parliaments towards that focus on legislation - as if there is a common understanding that this is what parliaments do and that this is what citizens want to know about. To note also the low focus on representation which is partly explained by the fact that parliaments' websites tend to concentrate on parliamentary outputs rather than parliamentary actors, and even less on political actors. To a large extent this is linked to parliaments' nature as collective and public institutions that need to be seen as apartisan.

Despite the fact that this analysis did not take into account the style and structure of parliamentary websites, focusing instead on contents, it did highlight the main parliamentary functions portrayed on parliaments' websites in Europe. It showed that often there is not a match between what parliaments do - their role - and what their websites show. To that extent it is not always clear if parliaments' websites are in fact enhancing parliamentary activity, though examples such as the French case seemed to indicate an enhancement of parliamentary activity through the variety of information it provides on its website. This analysis also raises questions about the processes that lead to the decision of what a parliamentary website should include. To what extent is this the realm of politicians, parliamentary staff, technicians, or all? To what extent are parliaments planning strategically the role of their websites or to what extent are these websites simply the result of ad-hoc decisions? These are questions to raise in future research together with a more comprehensive analysis of parliamentary websites.

\footnotetext{
9 From speaking to parliamentary staff at both the Parliaments in the Digital Age workshop, June 2007, Oxford, and at the World e-Parliament Conference 2008, November 2008, Brussels (GLOBAL CENTRE FOR ICT IN PARLIAMENT, 2008a; LESTON-BANDEIRA \& WARD, 2008).
}

Cristina Leston-Bandeira (c.c.leston-bandeira@hull.ac.uk)é Doutora em Ciência Política pela Universidade de Hull, na Inglaterra, e Professora do Departamento de Política e Estudos Internacionais na mesma instituição. 


\section{REFERENCES}

BERGMAN, T.; MÜLLER, W.; STRØM, K. \& BLOMGREN, M. 2006. Democratic Delegation and Accountability: Cross-National Patterns. In : STRØM, K.; MÜLLER, W. \& BERGMAN, T. (eds.). Delegation and Accountability in Parliamentary Democracies. Oxford : Oxford University.

COLEMAN, S. 2006. Parliamentary Communication in an Age of Digital Interactivity. Aslib Proceedings, London, v. 58, n. 5 , p. $375-80$.

GLOBAL CENTRE FOR ICT IN PARLIAMENT. 2008a. World e-Parliament Report 2008. New York : United Nations.

2008b. A Proposal for a Revised Set of Guidelines for Parliamentary Websites. Accessible at: http://www.ictparliament.org/ worldeparliamentconference $2008 /$ documentation/EN_Guidelines.pdf. Accessed : 1.Dec.2008.

2009. Mandate and Objectives. Accessible at : http://www.ictparliament.org/index.php/ inter-parl-organizations-mainmenu-171. Accessed : 16.Mar.2009.

HAYWARD, J. 2004. Parliament and the French Government's Domination of the Legislative Process. The Journal of Legislative Studies, Hull, v. 10, n. 2-3, p. 79-97.

INTERNATIONAL INSTITUTE FOR DEMOCRACYAND ELECTORALASSISTANCE. Web Site. 2009. Accessible at : http:// www.idea.int/. Accessed : 20.Mar.2009.

INTER-PARLIAMENTARY UNION. 2000. Guidelines for the Content and Structure of Parliamentary Web Sites. Accessible at: http:/ /www.ipu.org/cntr-e/web.pdf. Accessed : 28.Apr.2006

LEDUC, L.; NIEMI, R. \& NORRIS, P. (eds.). 2002. Comparing Democracies 2. London: Sage.

LESTON-BANDEIRA, C. 2007. The Impact of the Internet on Parliaments - a legislative studies framework. Parliamentary Affairs, Oxford, v. 60, n. 4, p. 655-674.
LESTON-BANDEIRA, C. \& WARD, S. (eds.). 2008. Parliaments in the Digital Age - Forum Discussion Paper. Oxford : Oxford Internet Institute. Accessible at: http:// www.oii.ox.ac.uk/research/publicOations/ FD13.pdf. Accessed : 2.Aug.2009.

NORRIS, P. 2001. Digital Divide : Civic Engagement, Information Poverty, and the Internet Worldwide. Cambridge : Cambridge University.

NORTON, P. (ed.). 1990. Parliaments in Western Europe. London : F. Cass.

1992. General Introduction. In : NORTON, P. (ed.). Legislatures. Oxford : Oxford University.

1994. The Legislative Powers of Parliament. In : FLINTERMAN, A.; HERINGA, A. \& WADDINGTON, L. The Evolving Role of Parliaments in Europe. Antwerp : Maklu.

(ed.). 1998. Parliaments and Governments in Western Europe. London : F. Cass.

NORTON, P. \& LESTON-BANDEIRA, C. 2005. The Impact of Democratic Practice on the Parliaments of Southern Europe. In : LESTONBANDEIRA, C. (ed.). Southern European Parliaments in Democracy. London : Routledge.

OÑATE, P. 2005. Parliament and Citizenship in Spain : Twenty-Five Years of a Mismatch? In : LESTON-BANDEIRA, C. (ed.). Southern European Parliaments in Democracy. London : Routledge.

PACKENHAM, R. 1970. Legislatures and political development. In : KORNBERG, A. \& MUSOLF, L. (eds.). Legislatures in Developmental Perspective. Durham : Durham University.

SAALFELD, T. 1998. The German Bundestag : Influence and Accountability in a Complex Environment. In : NORTON, P. (ed.). Parliaments and Governments in Western Europe. London : Frank Cass.

SETÄLÄ, M. \& GRÖNLUND, K. 2006. Parliamentary Websites : Theoretical and Comparative Perspectives. Information Polity, v. 11, p. 149-162. 
STRØM, K.; MÜLLER, W. \& BERGMAN, T. (eds.). 2006. Delegation and Accountability in Parliamentary Democracies. Oxford : Oxford University

THIÉBAULT, J.-L. 2006. France : Delegation and Accountability in the Fifth Republic. In : STRØM, K.; MÜLLER, W. \& BERGMAN, T. (eds.). Delegation and Accountability in Parliamentary Democracies. Oxford : Oxford University.

TRECHSEL, A.; KIES, R.; MENDEZ, F. \& SCHIMITTER, P. 2003. Evaluation of The Use of New technologies in Order to facilitate Democracy in Europe. Working Paper. Scientific and Technological Options Assessment Series. Accessible at : http:// edc.unige.ch/edcadmin/images/STOA.pdf. Accessed : 2.Aug.2009.

WHITE, S.; BATT, J. \& LEWIS, P. (eds.). 2007. Developments in Central and East European Politics 4. London : Palgrave.

WIBERG, M. 1994. Parliamentary Control in the Nordic countries : Forms of Questioning and Behavioural Trends. Helsinki : The Finnish Political Association.

\section{APPENDIX}

CODING FRAME FOR WEBSITES CONTENTS ANALYSIS

Level 1 - Content ${ }^{10}$

Legislation Is legislation output available? (Yes-1; No-0)

If yes, where? (First page link-1; Second page link-2; More than second-3)

Number of clicks to get to legislation (number)

Info given on legislation

- Original proposal (Yes-1; No-0)

- Author(s) (Yes-1; No-0)

- Link to author's biography (Yes-1; No-0)

- Amendments (Yes-1; No-0)

- Debate (Yes-1; No-0)

- Committee debate (Yes-1; No-0)

- Link to relevant committee

- Plenary debate (Yes-1; No-0)

- Committee reports (Yes-1; No-0)

- End result bill (Yes-1; No-0)

- Link to other relevant organisations associated with bill? (Yes-1; No-0)

Are these stages integrated? (Totally-1; Partly-2; Not at all-3)

If committee's main role is legislation:

- do committees have a separate section? (All do: 1; Most do:2; A few do: 3; None does: 4)

- is access given to committee reports? (Yes-1; No-0)

General assessment of way information about legislation is given (open)

10 The contents analysis also included two other levels, on Style and Structure, but these are not analysed in this article. 


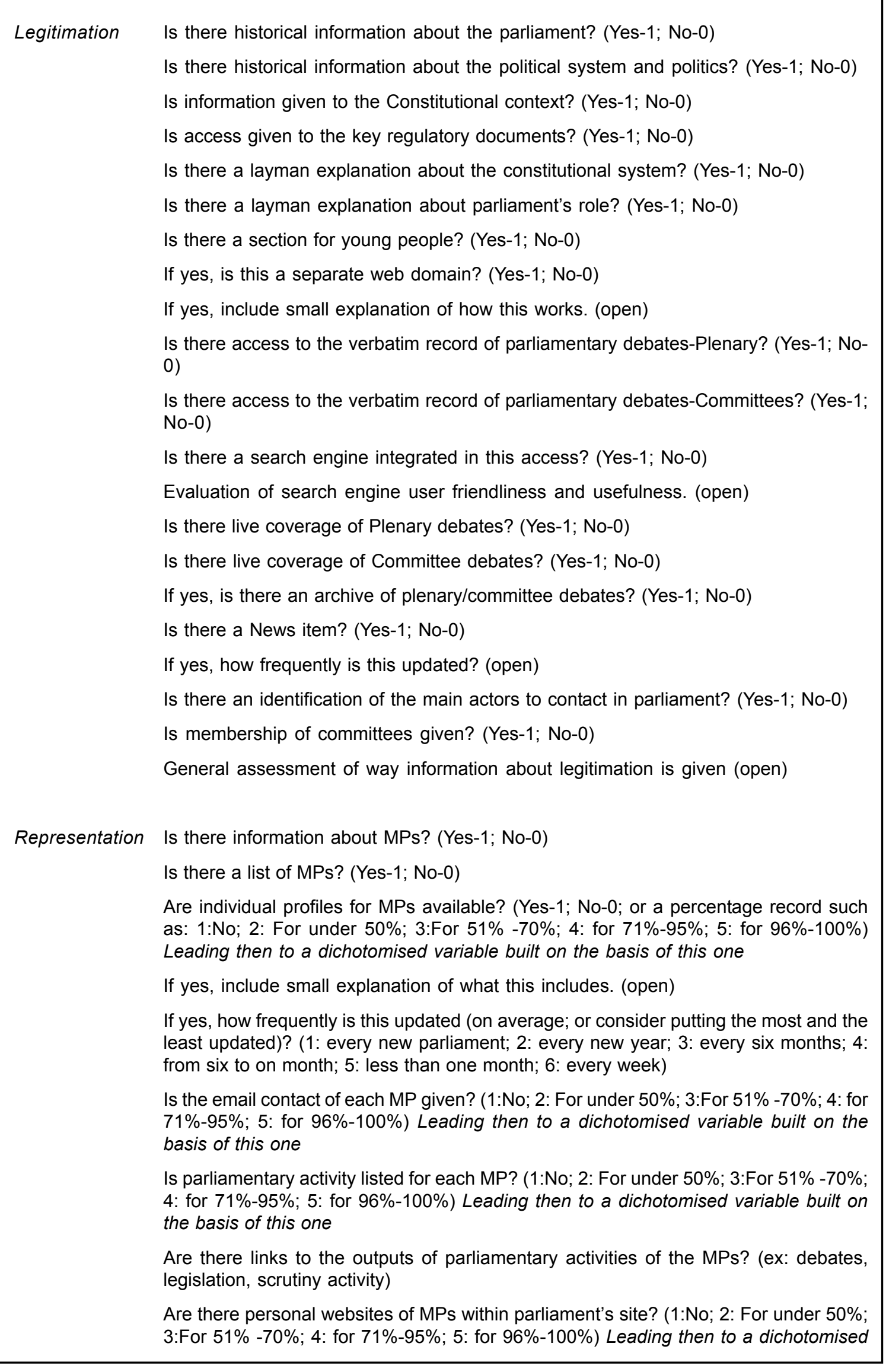


variable built on the basis of this one

Are links given to MPs' personal websites hosted outside parliament? (1:No; 2: For under 50\%; 3:For $51 \%-70 \%$; 4: for $71 \%-95 \%$; 5 : for $96 \%-100 \%$ ) Leading then to a dichotomised variable built on the basis of this one

Are there personal blogs of MPs within parliament's site? (1:No; 2: For under $50 \%$; 3:For $51 \%-70 \%$; 4: for $71 \%-95 \%$; 5 : for $96 \%-100 \%$ ) Leading then to a dichotomised variable built on the basis of this one

Are links given to MPs' blogs hosted outside parliament? (1:No; 2: For under $50 \%$; 3:For $51 \%-70 \%$; 4 : for $71 \%-95 \%$; 5 : for $96 \%-100 \%$ ) Leading then to a dichotomised variable built on the basis of this one

Are links given to MPs' facebook or myspace sites hosted outside parliament? (1:No; 2: For under $50 \%$; 3:For $51 \%-70 \%$; 4 : for $71 \%-95 \%$; 5 : for $96 \%-100 \%$ ) Leading then to a dichotomised variable built on the basis of this one

Do parties have a section within the parliament domain? (Yes-1; No-0)

Are links given to parties' websites? (Yes-1; No-0)

If yes, where? (open)

Do parliamentary groups have a section within the parliament domain? (Yes-1; No$0)$

Are links given to parliamentary groups' websites? (Yes-1; No-0)

General assessment of way information about representation is given (open)

Is scrutiny output available? (Yes-1; No-0)

If yes, where? (First page link-1; Second page link-2; More than second-3)

Number of clicks to get to scrutiny (number)

Info given on written questions

$$
\begin{aligned}
& \text { - text of the question (Yes-1; No-0) } \\
& \text { - Author(s) (Yes-1; No-0) } \\
& \text { - Reply (Yes-1; No-0) } \\
& \text { - Integration between the above (Yes-1; No-0) }
\end{aligned}
$$

Info given on oral questions

- text of the question (Yes-1; No-0)

- Author(s) (Yes-1; No-0)

- Reply (Yes-1; No-0)

- Link to debate (Yes to audio debate:1; Yes to written record of debate: 2; Yes, both of the previous ones:3; No:4)

- Integration between the above (Yes-1; No-0)

Info given on interpelations

$$
\begin{aligned}
& \text { - text of the interpelation (Yes-1; No-0) } \\
& \text { - Author(s) (Yes-1; No-0) }
\end{aligned}
$$

- Link to debate (Yes to audio debate:1; Yes to written record of debate: 2; Yes, both of the previous ones:3; No:4)

- Integration between the above (Yes-1; No-0)

Info given on Committees of enquiry 
- separate page for com. of enquiry? (Yes-1; No-0)

- text of original enquiry (Yes-1; No-0)

- Author(s) (Yes-1; No-0)

- Proceedings in separate page? (Yes-1; No-0)

- Link to debate (Yes to audio debate:1; Yes to written record of debate: 2; Yes, both of the previous ones:3; No:4)

- Integration between the above (Yes-1; No-0)

If committees' main role is scrutiny:

- do committees have a separate section? (All do: 1; Most do:2; A few do: 3; None does: 4)

- is access given to committee reports? (Yes-1; No-0)

General assessment of way information about scrutiny is given (open) 


\section{LES FONCTIONS PARLEMENTAIRES REPRÉSENTÉES SUR LES SITES WEB DU PARLEMENT EUROPÉEN}

Cristina Leston-Bandeira

Cet article s'appuie sur des données originaires d'une étude pilote sur les sites web de quinze parlements européens afin d'identifier quelles fonctions parlementaires y sont représentées. L'étude pilote porte sur une analyse de contenus centrée sur quatre fonctions parlementaires : législation, légitimation, représentation et élection, pour établir la dimension que chacune de ces fonctions a dans les sites web étudiés. En raison de la difficulté que les parlements ont d'être perçu par le public, leurs sites deviennent un outil important de diffusion du travail parlementaire. Nous ne connaissions pas encore ce que ces sites représentaient ni s'il s'agissait d'une activité parlementaire. Ces sites seraient-ils un reflet du travail parlementaire ? A quel point expriment-ils le débat politique ? Parlent-ils de tous les rôles joués par les palementaires? Cet article montre que c'est la dimension législation qui est mise en relief dans ces sites en Europe tandis que la dimension représentation y est moins importante. Cela peut nous expliquer pourquoi quelques sites du parlement sont considerés comme trop denses et difficiles d'être utilisés. Nous montrons aussi que ces sites tendent à mettre en évidence la production parlementaire au détriment des acteurs parlementaires. En fonction de leur représentation institutionnelle collective, les parlements sont prudents en ce qui concerne les politiciens ou les partis ; ils préfèrent donc mettre l'accent sur ce que les parlementaires produisent (lois, demandes, débats, etc.). Encore une fois, c'est ce qui explique pourquoi les sites web des parlements ne sont pas si engagés comme l'on le souhaiterait, tout simplement parce qu'ils ne sont pas tenus de réfleter le débat politique, mais plutôt de le rendre plus facile.

MOTS-CLÉS : Internet ; parlements européens ; sites web parlementaires. 